\title{
Cervical Cancer cT2a1 TNM Finding v8
}

National Cancer Institute

\section{Source}

National Cancer Institute. Cervical Cancer CT2a1 TNM Finding v8. NCI Thesaurus. Code C139696.

Cervical carcinoma invading beyond the uterus but not to the pelvic wall or to lower third of vagina without parametrial invasion. Clinically visible lesion $4.0 \mathrm{~cm}$ or less in greatest dimension. (from AJCC 8th Ed.) 